\title{
PROBLEMATIKA KEWENANGAN MENETAPKAN KERUGIAN KEUANGAN NEGARA DALAM PRAKTIK PERADILAN TINDAK PINDANA KORUPSI
}

\author{
Hotma P. Sibuea ${ }^{1}$, Dwi Seno Wijanarko ${ }^{2}$, Gatot Efrianto ${ }^{3}$
}

\begin{abstract}
As an act against the law, corruption is one of the criminal acts that cause state financial loss. According to Law No. 15 article 10 of 2006, authority to declare state financial loss due to violation of law like corruption is the authority of Badan Pemeriksa Keuangan (BPK). However, investigator, on the contrary, assigns BPKP to declare state financial loss because of corruption. It is a violation against the law and constitution. In accordance with the act of violation, there are two legal issues which are going to be investigated. First, does the act of declaring state financial loss due to corruption as violation against the law conducted by BPKP can be categorized as an arbitrary act? Secondly, is the act of declaring state financial loss due to corruption as violation against the law conducted by BPKP a violation against the constitutional law principle which is separation of power? This research uses juridical-normative methodology. The result of this research generates two conclusions. First, the act of BPKP mentioned above is an arbitrary act. Secondly, the arbitrary act of BPKP is a violation against constitutional law principle, which is separation of power. There are two recommendations that can be delivered. First, an amendment should be made on Law 20 No. 31 of 1999 on Corruption Eradication juncto Law No.20 of 2001 and Law No. 15 of 2006. Secondly, both law need to add a section or an article on "Declaring the state financial loss conducted by an institution other than BPK is not acceptable or null and void."
\end{abstract}

Keywords: Corruption, actions against the law, state loss

\begin{abstract}
ABSTRAK
Sebagai perbuatan melawan hukum, tindak pidana korupsi adalah tindak pidana yang mengakibatkan kerugian keuangan negara. Menurut Pasal 10 Undang-undang Nomor 15 Tahun 2006, wewenang menetapkan kerugian keuangan negara akibat perbuatan melawan hukum seperti tindak pidana korupsi adalah wewenang Badan Pemeriksa Keuangan. Namun, dalam praktik, instansi yang diminta penyidik untuk menetapkan kerugian keuangan negara dalam tindak pidana korupsi adalah Badan

1 Dosen Tetap Fakultas Hukum Universitas Bhayangkara Jakarta Raya, Jalan Raya Perjuangan, Marga Mulya, Bekasi Utara, Kota Bekasi. Email: pardomuansibuea58@gmail.com

${ }^{2}$ Dosen Tetap Fakultas Hukum Universitas Bhayangkara Jakarta Raya, Jalan Raya Perjuangan, Marga Mulya, Bekasi Utara, Kota Bekasi.

${ }^{3}$ Dosen Tetap Fakultas Hukum Universitas Bhayangkara Jakarta Raya, Jalan Raya Perjuangan, Marga Mulya, Bekasi Utara, Kota Bekasi.
\end{abstract}


Pengawas Keuangan dan Pembangunan (BPKP). Tindakan tersebut adalah tindakan yang bertentangan dengan undang-undang.Dalam hubungan dengan tindakan tersebut, masalah hukum yang hendak diteliti ada 2 (dua) yakni sebagai berikut. Pertama, apakah tindakan BPKP menetapkan kerugian keuangan negara dalam tindak pidana korupsi sebagai perbuatan melawan hukum dapat dikategorikan tindakan sewenang-wenang? Kedua, apakah tindakan BPKP menetapkan jumlah kerugian keuangan negara dalam tindak pidana korupsi sebagai perbuatan melawan hukum dapat dikategorikan sebagai pelanggaran sendi-sendi hukum konstitusional pemisahan kekuasaan? Metode penelitian yang dipakai dalam penelitian adalah yuridis-normatif.Sebagai hasil penelitian, ada 2 (dua) simpulan yakni sebagai berikut. Pertama, tindakan BPKP yang dimaksud di atas adalah tindakan sewenang-wenang. Kedua, tindakan sewenang-wenang BPKP tersebut termasuk pelanggaran sendi hukum pemisahan kekuasaan. Ada 2 (dua) saran yang dikemukakan yakni sebagai berikut. Pertama, Undang-undang Tindak Pidana Korupsi Nomor 31 Tahun 1999 juncto UU Nomor 20 Tahun 2001 dan undangundang Nomor 15 Tahun 2006 perlu diamandemen. Kedua, dalam kedua undangundang tersebut perlu ditambahkan ayat atau pasal yang mengatur sebagai berikut "Penetapkan kerugian keuangan negara yang dilakukan badan atau organ selain Badan Pemeriksa Keuangan adalah tidak sah atau batal demi hukum."

Kata kunci: tindak pidana korupsi, perbuatan melawan hukum, kerugian negara

\section{PENDAHULUAN}

Salah satu jenis tindak pidana korupsi yang diatur dalam Pasal 2 ayat (1) UU Nomor 31 Tahun 1999 adalah tindak pidana korupsi yang bersifat pokok. ${ }^{4}$ Tindak pidana korupsi tersebut adalah bentuk dasar tindak pidana korupsiyang mengakibatkan kerugian keuangan negara. ${ }^{5}$ Tindak pidana korupsi dalam Pasal 2 ayat (1) UU Nomor 31 Tahun 1999 adalah tindak pidana korupsi yang dilakukan pejabat negara dengan menyalahgunakan kewenangan, kesempatan atau sarana yang ada pada jabatan atau kedudukan.Jenis tindak pidana korupsi yang lain diatur dalam Pasal 3 UU Nomor 31 Tahun 1999 dengan karakteristik yang berbeda dari tindak pidana korupsi yang disebut di atas. Tindak pidana korupsi dalam Pasal 3 UU Nomor 31 Tahun 1999 menjangkau adressat norma yang lebih luas daripada tindak pidana korupsi dalam Pasal 2 ayat (1) UU Nomor 31 Tahun 1999. ${ }^{6}$ Pasal 3

\footnotetext{
${ }^{4}$ Ridwan Khairandy, Hanafi Amrani dan Dolli Setiawan Ritonga, Korupsi Kerugian Keuangan negara di BUMN (Yogjakarta, UII Press, 2018), hlm. 88-89.

${ }^{5}$ Pasal 2 ayat (1) UU Nomor 31 Tahun 1999 mengatur sebagai berikut "Setiap orang yang dengan tujuan menguntungkan diri sendiri atau orang lain atau suatu korporasi menyalahgunakan kewenangan, kesempatan atau sarana yang ada padanya karena jabatan atau kedudukan yang dapat merugikan keuangan negara atau perekonomian negara dipidana dengan pidana penjara seumur hidup atau pidana penjara paling singkat 1 (satu) tahun dan paling lama 20 (dua puluh) tahun dan atau denda paling sedikit Rp 50.000.000 (lima puluh juta rupiah) dan paling banyak Rp. 1.000.000.000 (satu miliar rupiah)."

${ }^{6}$ Andi Hamzah, Delik-delik Tertentu (Speciale Delicten) di dalam KUHP (Jakarta, Sinar Grafika, 2015), hlm. 100.
} 
UU Nomor 31 Tahun 1999 berlaku bagi setiap orang yang memperkaya diri sendiri atau orang lain dengan melawan hukum dan merugikan keuangan negara. ${ }^{7}$

Salah satu elemen tindak pindana korupsi adalah kerugian keuangan negara. Kerugian yang disebut di atas adalah kerugian keuangan negara yang bersifat nyata sesuai dengan Putusan MK Nomor: 003/PUU-IV/2006. ${ }^{8}$ Menurut Pasal 10 UU Nomor 15 Tahun 2006 tentang Badan Pemeriksa Keuangan, organ negara yang berwenang menetapkan jumlah kerugian keuangan negara sebagai akibat perbuatan melawan hukum adalah Badan Pemeriksa Keuangan (BPK). ${ }^{9}$ Wewenang BPK menetapkan kerugian negara sebagai akibat perbuatan melawan hukum adalah wewenang atributif yang bersumber dari undang-undang.Dalam tindak pidana korupsi,unsur kerugian keuangan negara terjadi akibat perbuatan melawan hukum karena kesengajaanatau kelalaian sehingga kerugian keuangan negara tersebut harus ditetapkan BPK.Pasal 10 UU Nomor 15 Tahun 2006 tentang BPK adalah salah satu sendi hukum konstistusional yang harus dihormatidalam praktik peradilan tindak pidana korupsi. Gambaran wewenang BPK untuk menetapkan jumlah kerugian negara dalam tindak pidana korusi sebagai perbuatan melawan hukum adalah gambaran ideal berdasarkan ketentuan UUD 1945 dan UU Nomor 15 Tahun 2006 tentang BPK.

Dalam praktik peradilan tindak pidana korupsi, institusi yang sering terlibat dalam penetapan jumlah kerugian negara dalam tindak pidana korupsi adalah BPKP. ${ }^{10}$ BPKP terlibat dalam penetapan jumlah kerugian keuangan negara baik secara langsung atau lewat perwakilannya yang berkedudukan di propinsi. Kasus yang relevan dikemukakan sebagai contoh adalah kasus tindak pidana korupsi dalam Putusan Mahkamah Agung Nomor: 2185 K/Pid.Sus/2016 Tanggal 29 Mei 2017. Berdasarkan putusan MA, terpidana dihukum 7 (tujuh) tahun penjara dan denda sebesar Rp.200.000.000 (dua ratus juta) rupiah.Padahal, dalam perkara $a$ $q u o$, BPK menyatakan tidak ada kerugian keuangan negara tetapi kelebihan pembayaran kepada terpidana. Kasus lain adalah kasus tindak pidana korupsi dalam Putusan Mahkamah Agung Nomor:302 K/Pid.Sus/2017 Tanggal 15 Maret 2017. Berdasarkan putusan MA, terdakwa divonis 5 (lima) tahun penjara dan denda Rp.200.000.000 (dua ratus juta rupiah) karena dianggap terbukti bersalah melakukan tindak pidana korupsi yang merugikan keuangan negara. Padahal, dalam perkara a quo, BPK menyatakan tidak adakerugian keuangan negara tetapi kelebihan pembayaran kepada terdakwa. Berdasarkan Putusan MA tersebut,

${ }^{7}$ Pasal 3 UU Nomor 31 Tahun 1999 mengatur sebagai berikut "Setiap orang yang secara melawan hukum melakukan perbuatan memperkaya diri sendiri atau orang lain atau suatu korporasi yang dapat merugikan keuangan negara atau perekonomian negara dipidana dengan pidana penjara seumur hidup atau pidana penjara paling singkat 4 (empat) tahun dan paling lama 20 (dua puluh) tahun dan denda paling sedikit Rp.200. 000. 000 (dua ratus juta rupiah) dan paling banyak Rp. 1.000.000.000 (satu miliar rupiah.”

${ }^{8}$ Putusan Mahkamah Konstitusi Nomor: 003/PUU-IV/2006.

${ }^{9}$ Pasal 10 ayat (1) Undang-undang Nomor 15 Tahun 2006 mengatur sebagai berikut "BPK menilai dan/atau menetapkan jumlah kerugian keuangan negara yang diakibatkan oleh perbuatan melawan hukum baik sengaja maupun lalai yang dilakukan oleh bendahara, pengelola BUMN/BUMD dan lembaga atau badan lain yang menyelenggarakan penelolaan keuangan negara."

${ }^{10}$ Beberapa kasus penghitungan kerugian keuangan negara oleh BPKP yang digugat di PTUN tetapi ditolak PTUN antara lain adalah kasus (1) Putusan PTUN Jakarta Timur Nomor: 111/G//20/2014/PTUN Jkt, (2) Putusan PTUN Jakarta Nomor 250/G//2014 PTUN Jakarta, (3) Putusan PTUN Surabaya Nomor 09/G/2015/PTUN-Sby dan lain-lain. 
terpidana divonis 5 (lima) tahun dan denda sebesar Rp. 200.000 .000 (dua ratus juta rupiah) karena melanggar Pasal 2 UU Nomor 31 Tahun 1999 menurut pertimbangan majelis hakim. ${ }^{11}$ Dalam kasus tindak pidana korupsi tersebut, kerugian keuangan negara dihitung dan ditetapkan BPKP dan bukan oleh BPK. ${ }^{12}$

Keterlibatan BPKP dalam penetapan jumlah kerugian negara dalam tindak pidana korupsi sebagai perbuatan melawan hukum adalah penyimpangan dari ketentuan hukum yang bersifat ideal. Tindakan BPKP tersebut adalah bentuk pelanggaran terhadap UUD 1945 dan UU Nomor 15 Tahun 2006.Fenomena pelanggaran tersebut sekaligus merupakan dari penyimpangan norma-norma hukum konstitusional.Sudah barang tentu, pelanggaran BPKP terhadap normanorma hukum tersebut di atas mengandung konsekuensi dan akibat hukum tertentu. Tindakan atau perbuatan BPKP tersebut melahirkan problematika hukum yang menarik untuk diteliti. Berdasarkan paparan di atas, ada 2 (dua) problematika hukum yang dirumuskan sebagai masalah penelitian.Kedua problematika hukum tersebut adalah sebagai berikut. Pertama, apakah tindakan Badan Pemeriksa Keuangan Pemerintah (BPKP)yang menetapkan kerugian keuangan negara dalam tindak pidana korupsi sebagai perbuatan melawan hukum dapat dikategorikan sebagai tindakan sewenang-wenang? Kedua, apakah BPKP yang menetapkan kerugian keuangan negara dalam tindak pidana korupsi sebagai perbuatan melawan hukum dapat dikategorikan sebagai pelanggaran terhadap sendi-sendi hukum konstitusional yakni sendi pemisahan kekuasaan dalam bingkai Negara Hukum Pancasila sebagai negara hukum-kesejahteraan yang demokratis?

\section{METODE PENELITIAN}

Ilmu Hukum adalah ilmu praktis-Normologis yang otoritatif.Objek kajian Ilmu Hukum adalah norma-norma hukum positif yang berlaku dalam suatu negara (masyarakat) beserta dengan asas-asas hukum dan doktrin-doktrin hukum.Ilmu Hukum bertujuan menyusun argumentasi hukum untuk menghasilkan pendapat hukum dalam rangka membenarkan atau menyangkal pendapat hukum. Dalam bingkai pemahaman seperti dikemukakan di atas, metode penelitian hukum yang dipergunakan dalam penelitian ini adalah metode penelitian yuridis-normatif. Objek kajian penelitian adalah bahan-bahan hukum yang terdiri atas bahan hukum primer, sekunder dan tersier.

\section{PEMBAHASAN}

\section{Tindakan Sewenang-wenang BPKP Dalam Penetapan Jumlah Kerugian Keuangan Negara Dalam Tindak Pidana Korupsi Sebagai Perbuatan Melawan Hukum}

Landasan untuk memperbincangkan masalah hukum yang dikemukakan di atas adalah pengertian konsepsi tindakan (perbuatan) sewenang-wenang. Tindakan (perbuatan) sewenang-wenang adalah tindakan yang dilakukan pejabat (badan)

\footnotetext{
${ }^{11}$ Putusan Mahkamah Agung Nomor 302 K/PID.SUS/2017 tanggal 15 Maret 2017.

12 Putusan Mahkamah Agung Nomor 302 K/PID.SUS/2017 tanggal 15 Maret 2017 pada halaman 156.
} 
pemerintah tanpa dasar wewenang yang bersumber dari undang-undang dasar atau undang-undang atau tindakan organ (badan) pemerintah yang tanpa dasar hukum yang jelas. ${ }^{13}$ Dalam tindakan hukum yang dilakukan pejabat (badan) pemerintah, elemen utama tindakan hukum pemerintahan adalah wewenang. Namun, elemen wewenang tidak terdapat dalam tindakan (perbuatan) sewenang-wenang, Titik fokus perhatian dalam perbincangan tentang tindakan (perbuatan) sewenangwenang adalah unsur wewenang. Dalam pengertian yang lebih luas, tindakan sewenang-wenang dapat dianggap sebagai tindakan pejabat pemerintah yang tidak mempertimbangkan semua faktor yang relevan dengan kasus yang bersangkutan secara lengkap dan wajar sehingga tanpak atau terasa bagi orang-orang yang berpikir sehat (normal) ada ketimpangan atau kekeliruan. ${ }^{14}$ Faktor utama yang harus dan patut dipertimbangkan sebelum organ (badan) pemerintah melakukan tindakan (perbuatan) adalah wewenang pejabat yang bersangkutan untuk melakukan tindakan (perbuatan).

Pengertian yang terkandung dalam konsep hukum tindakan (perbuatan) sewenang-wenang adalah alat untuk membangun argumentasi dalam rangka melakukan penilaian terhadap tindakan BPKP dalam penetapan kerugian keuangan negara dalam tindak pidana korupsi sebagai perbuatan melawan hukum. Apakah BPKP memiliki wewenang menetapkan kerugian keuangan negara dalam tindak pidana korupsi sebagai perbuatan melawan hukum? Dasar hukum untuk mengetahui kewenangan atau ketidakwenangan BPKP menetapkan kerugian keuangan negara dalam tindak pidana korupsi sebagai perbuatan melawan hukum adalah Peraturan Presiden Nomor 192 Tahun 2014. Apakah Perpres Nomor 192 Tahun 2014 melimpahkan wewenang kepada BPKP untuk menetapkan kerugian keuangan negara dalam tindak pidana sebagai perbuatan melawan hukum? Ada 2 (dua) kemungkinan yang akandiperoleh sebagai hasil penelitian yakni sebagai berikut. Pertama, dalam hal Peraturan Presiden Nomor 192 Tahun 2014 memberikan wewenang kepada BPKP untuk menetapkan kerugian keuangan negara dalam tindak pidana korupsisebagai perbuatan melawan hukum, tindakan (perbuatan) BPKP tersebut tidak termasuk kategori tindakan (perbuatan) sewenangwenang atau tindakan yang tidak layak (patut). Kedua, dalam hal, Peraturan Presiden Nomor 192 Tahun 2014 tidak memberikan wewenang kepada BPKP untuk menetapkan kerugian keuangan negara dalam tindak pidana korupsi sebagai perbuatan melawan hukum, tindakan (perbuatan) BPKP tersebut termasuk kategori tindakan sewenang-wenang atau tindakan pemerintahan yang tidak layak. ${ }^{15}$

Karakteristik Peraturan Presiden Nomor 192 Tahun 2014 sebagai peraturan perundang-undang yang menjadi dasar hukum keberadaan BPKP mengindikasikan urgensi tugas dan fungsi BPKP. Seandainya, fungsi dan tugas BPKP dianggap penting dalam praktik penyelenggaraan negara, dasar hukum keberadaan BPKP kemungkinan adalah undang-undang.Sebagai organ pemerintah, keberadaaan BPKP diatur dalam Pasal 1 ayat (1) Perpres Nomor 192 Tahun 2014 sebagai berikut "Badan Pengawas Keuangan dan Pembangunan selanjutnya disingkat BPKP

${ }^{13}$ Yopie Morya Immanuel Patiro, Diskresi Publik dan Tindak Pidana Korupsi (Bandung, Keni Media, 2012), hlm. 172. hlm. 132 .

${ }^{14}$ A'an Effendi dan Freddy Poernomo, Hukum Administrasi (Jakarta, Sinar Grafika, 2017), hlm. 107.

${ }^{15}$ Bachsan Mustafa, Pokok-pokok Hukum Administrasi Negara (Bandung, Alumni, 1979), 
merupakan aparat pengawas intern pemerintah." Sifat dan hakikat BPKP sebagai suatu instansi adalah sebagai badan pengawas internal pemerintah. Sebagai konsekuensinya, tugas dan fungsi BPKP sebagai badan pengawas internal hanya berlaku dalam lingkungan organisasi pemerintah.Sebagai konsekuensinya, segenap tindakan BPKP berlaku dalam lingkungan pemerintah semata-mata.Ketentuan Pasal 1 ayat (1) Peraturan Presiden Nomor 193 Tahun 2014 tersebut mencerminkan pembatasan fungsi dan tugas BPKP. Dalam konteks pengawasan dan pembangunan yang berkaitan dengan keuangan negara, segenap tindakan BPKP dapat ditujukan hanya kepada lingkungan internal pemerintah semata-mata.

Pasal 1 ayat (2) Perpres Nomor 192 Tahun 2014 menetapkan kedudukan BPKP sebagai berikut "BPKP sebagaimana dimaksud pada ayat (1) berada di bawah dan bertanggung jawab kepada Presiden."Kedudukan BPKP berada di bawah dan bertanggung jawab kepada Presiden.BPKP memiliki kedudukan yang tidak sederajat dengan Presiden, DPR, DPD, MPR, MA-MK dan BPK.Bahkan, dalam struktur organisasi pemerintah, kedudukan BPKP lebih rendah daripada Menteri sebagai bawahan Presiden.Kedudukan BPKP hanya sederajat dengan Eselon I sehingga kedudukan BPKP berada jauh di bawah Presiden dan Menteri.Kedudukan BPKP yang lebih rendah daripada Presiden atau BPK merupakan bukti karakteristik tugas dan fungsi yang diserahkan kepada BPKP adalah tugas dan fungsi pemerintahan yang tidak signifikan dalam praktik penyelenggaraan negara. Kedudukan BPKP seperti dipaparkan di atas menunjukkan, BPKP adalah bukan organ otonom. BPKP tidak memiliki wewenang mandiri (otonom) untuk menetapkan kebijakan. Bahkan, kedudukan BPKP tidak sederajat dengan kementerian yang sebagai unit yang diperiksa BPKP.

Sesuai dengan Perpres 192 Tahun 2014, tugas BPKP adalah tugas yang diperoleh dari Presiden sebagai pimpinan kekuasaan pemerintah (eksekutif). Tugas BPKP bersumber dari dan merupakan salah satu aspek khusus tugas Presiden berdasarkan Pasal 4 ayat (1) UUD 1945.Secara khusus, Presiden mendistribusikan tugas pengawasan keuangan dan pembangunan kepada BPKP. Ruang lingkup tugas pengawasan keuangan pemerintah dan pembangunan BPKP adalah tugas yang terbatas dengan ruang lingkup yang terbatas. Pembatasan ruang lingkup tugas dan fungsi tersebut adalah gambaran dari penerapan sendi hukum pemisahan kekuasaan dalam lingkungan organisasi pemerintah.Pembatasan tugas BPKP berdasarkan sendi pemisahan kekuasaan dilakukan untuk mencegah pelanggaran terhadap batasbatas tugas dan fungsi organ-organ pemerintah di bidang pengawasan.Pembatasan tugas-tugas segenap organ pemerintah termasuk BPKP dalam pengawasan dan pembanguan harus berpedoman pada sendi hukum pemisahan kekuasaan sebagai salah satu sendi hukum utama dalam Negara Hukum Pancasila.

Dalam hubungan dengan tugas dan fungsi BPKP, sendi pemisahan kekuasaan sebagai salah satu sendi utama UUD 1945 mengandung makna pembatasan ruang lingkup tugas pengawasan keuangan BPKP.Sendi pemisahan kekuasaan mengandung konsekuensi ruang lingkup tugas dan fungsi pengawasan keuangan BPKP berlaku hanya dalam lingkungan organisasi pemerintah.Tugas BPKP yang bersifat terbatas mengakibatkan BPKP tidak memiliki tugas apalagi wewenang melakukan pengawasan keuangan di luar organisasi pemerintah seperti dalam tindak pidana korupsi sebagai perbuatan melawan hukum yang 
mengakibatkan kerugian keuangan negara. Ketiadaan tugas atau wewenang BPKP melakukan tugas dan fungsi seperti di atas mengandung arti BPKP adalah organ pemerintah yang kedudukan dan sewenangnya tidak sederajat dengan BPK. Tugas BPKP yang terbatas berpengaruh terhadap hasil BPKP.Sebagai organ pemeriksa, BPKP tidak memiliki kemampuan "memaksa" organ pemerintah yang diawasi untuk melaksanakan arahan dan masukan BPKP.Ahmad Fikri Hadin mengemukakan kelemahan BPKP sebagai badan pengawas keuangan pemerintah yang tidak otonom karena kewenangan yang terbatas sebagai berikut "Secara filosofis, independensi badan sangat menentukan keobjektifan mutu pemeriksaan.Independensi ini meliputi keuangan, sumber daya dan organisasi serta posisi badan itu sendiri dalam struktur pemerintahan terutama terhadap unit yang

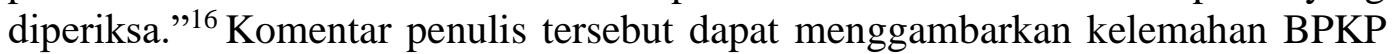
sebagai organ pengawas keuangan pemerintah. Fenomena pengabaian tugas-tugas pengawasan yang dilakukan BPKP karena kedudukan organ pemerintah tersebut yang rendah jika dibandingkan dengan BPK.

BPKP adalah organ pemerintah yang bersifat "tidak utuh" karena tidak memiliki wewenang. Ketiadaan wewenang BPKP sebagai organ pemerintah mengandung makna BPKP adalah bukan subjek hukum publik yang utuh. Keadaan dan kondisi BPKP tersebut berbeda dari keberadaan DPR, DPD, MPR dan BPK sebagai subjek hukum publik yang utuh karena memiliki wewenang dan tugas. BPKP adalah bukan subjek hukum publik yang utuh jika ditinjau dari sudut pandang hukum publik karena BPKP "hanya" memiliki fungsi dan tugas tanpa wewenang. Dari sudut pandang hukum publik, sebagai konsekuensi yuridisnya, BPKP adalah bukan organ pemerintah yang bersifat mandiri atau otonom. Sebagai konsekuensinya, BPKP tidak memiliki kemampuan (kekuatan) juridis untuk menghasilkan suatu tindakan atau keputusan hukum yang bersifat mengikat pihak lain. Keadaan BPKP sebagai "quasi" organ pemerintah dapat dikemukakan dengan redaksi kalimat yang berbeda yakni sebagai berikut. BPKP tidak memiliki wewenang menetapkan keputusan yuridis yang berpengaruh terhadap kedudukan hukum seorang individu warga negara. BPKP tidak memiliki wewenang untuk mempengaruhi atau mengubah keadaan hukum warga masyarakat. ${ }^{17}$

Sebagai organ pengawasan keuangan internal pemerintah, tugas-tugas BPKP berlaku dalam lingkungan organisasi pemerintahtetapi tidak memiliki kekuatan mengikat terhadap organ pemerintah.Pasal 2 Perpres Nomor 192 Tahun 2014 mengatur sebagai berikut "BPKP mempunyai tugas menyelenggarakan urusan pemerintahan di bidang pengawasan keuangan negara/daerah dan pembangunan nasional.'Dalam rangka tugas tersebut, menurut Pasal 3 Perpres Nomor 192 Tahun 2014, BPKP melaksanakan fungsi (1) merumuskan kebijakan nasional pengawasan internal terhadap akuntabilitas keuangan, (2) melaksanakan audit, (3) melakukan pengawasan internal, (4) memberikan konsultasi terkait dengan menejemen resiko, (5) melakukan pengawasan terhadap perencanaan dan pelaksanaan program dan/atau kegiatan yang dapat menghambat kelancaran

${ }^{16}$ Ahmad Fikri Hadin, Eksistensi Badan Pengawasan Keuangan dan Pembangunan di Era Otonomi Daerah (Yogjakarta, Bantul, Genta Press, 2013), hlm. 45.

${ }^{17}$ Indroharto, 'Asas-asas Umum Pemerintahan Yang Baik' dalam Paulus Effendi Lotulung "Himpunan Makalah Azaz-azaz Umum Pemerintahan Yang Baik (A.A.U.P.B.) (Bandung, Citra Aditya Bhakti, 1994), hlm. 143. 
pembangunan dan lain-lain. Wewenang untuk menetapkan jumlah kerugian keuangan negara dalam tindak pidana korupsi tidak disebut sama sekali dalam Perpres 192 Tahun 2014. BPKP tidak memiliki tugas dan wewenang yang berkaitan dengan penetapan jumlah kerugian keuangan negara dalam tindak pidana korupsi sebagai perbuatan melawan hukum karena kesengajaan atau kelalaian.

Dalam kajian hukum publik, subjek hukum publik yang otonom (mandiri) memiliki wewenang, tugas dan fungsi yang tertentu. Namun, kondisi hukum yang lazim melekat pada subjek hukum publik tersebut tidak terdapat pada BPKP sebagai “organ pemerintah." Perpres Nomor 192 Tahun 2014 menyebutkan dan mengatur hanya beberapa tugas tetapi tidak mengatur wewenang BPKPsama sekali. Deskripsi tugas-tugas dan fungsi BPKP yang dipaparkan di atas dapat menggambarkan eksistensi BPKP sebagai organ pengawas keuangan internal pemerintah yang berbeda tugasnya dari BPK sebagai badan pemeriksa pengelolaan dan pertanggungjawaban keuangan negara. Gambaran fungsi dan tugas tersebut membuktikan BPKP sama sekali tidak memiliki wewenang sebagai organ pemerintah. BPKP memiliki tugas dan fungsi semata-mata dalam konteks pengawasan keuangan dan pembangunan tanpa wewenang. Konsekuensi keberadaan BPKP sebagai "quasi" organ pemerintah mengakibatkan keputusan BPKP tidak mengikat organ pemerintah dalam lingkungan organisasi pemerintah dan individu. Fenomena organ publik yang tidak memiliki wewenang kecuali fungsi dan tugas mengandung arti organ tersebut tidak termasuk kategori "organ negara" atau "organ pemerintah." Dalam teori hukum tata negara, dalam arti yang utuh, organ negara atau pemerintah harus memiliki (1) kedudukan, (2) fungsi, (3) wewenang dan (4) tugas. Jika salah satu aspek tidak terdapat pada organ publik, keadaan tersebut mengandung arti organ tersebut adalah bukan organ negara atau organ pemerintah dalam arti yang utuh. Keadaan seperti dikemukakan di atas terdapat pada BPKP.Kondisi tersebut mengandung arti, kehadiran organ BPKP dalam sistem pemerintahan dan sistem ketatanegaraan Indonesia memilliki arti yang tidak signifikan.

Sebagai akhir perbincanganmengenai prblematika hukum yang berkenaan tindakan BPKP dalam penetapan kerugian keuangan negara dalam tindak pidana korupsi sebagai perbuatan melawan hukum, penulis mengemukakan simpulan sebagai berikut.BPKP adalah bukan organ pemerintah yang bersifat utuh dalam arti yuridis melainkan "quasi organ."Alasannya, BPKP tidak memiliki wewenang sebagai salah satu predikat utama organ negara atau pemerintah kecuali tugas dan fungsi.Sebagai konsekuensinya, BPKP tidak memiliki kemampuan menghasilkan tindakan hukum atau keputusan hukum yang mengikat dan mempengaruhi kedudukan hukum pihak lain seperti dikemukakan Indroharto. Ruang lingkup tugas dan fungsi BPKP berlaku hanya dalam lingkungan organisasi pemerintah.Bahkan, keputusan BPKP tidak mengikat organ pemerintah dalam lingkungan organisasi pemerintah.Berdasarkan beberapa alasan yang dikemukakan di atas, penulis dapat menarik simpulan BPKP tidak memiliki wewenang melakukan tindakan hukum atau keputusan hukum dalam penetapan kerugian keuangan negara dalam tindak pidana korupsi sebagai perbuatan melawan hukum yang mengakibatkan kerugian keuangan negara.Sesuai konsekuensinya, penulis dapat mengemukakan tindakan BPKP dalam penetapan kerugian keuangan negara dalam tindak pidana korupsi 
sebagai perbuatan melawan hukum adalah tindakan sewenang-wenang atau tindakan yang dilakukan tanpa wewenang.

\section{Tindakan BPKP Sebagai Pelanggaran Terhadap Sendi Pemisahan Kekuasaan Sebagai Sendi Hukum konstitusional Dalam bingkai Negara Hukum Pancasila Sebagai Negara Hukum-Kesejahteraan yang Demokratis}

Apakah tindakan BPKP dalam penetapan jumlah kerugian keuangan negara dapat dikategorikan sebagai pelanggaran sendi pemisahan kekuasaan sebagai salah satu sendihukum konstitusional dalam Negara Hukum Pancasila sebagai negara hukum kesejahteraan demokratis? Argumentasi yang dibangun untuk menjawab pertanyaan di atas bertitik tolak dari pengertian sendi pemisahan kekuasaan. Sendi pemisahan kekuasaan mengandung arti setiap setiap organ penyelenggara negara memiliki batas-batas wewenang, tugas dan fungsi ditetapkan dalam konstitusi atau undang-undang untuk mencegah konsentrasi kekuasaan dan rezim pemerintahan tirani yang bertindak sewenang-wenang. ${ }^{18}$ Doktrin klasik pemisahan kekuasaan mengajarkan pemisahan kekuasaan di antara kekuasaan legislatif, eksekutif dan judisial. ${ }^{19}$ Namun, dalam praktik penyelenggaraan negara zaman moderen, sendi (prinsip) pemisahan kekuasaan juga diterapkan dalam spektrum yang lebih luas yang mencakup segenap organ penyelenggara negara dalam arti luas. Sendi hukum konstitusional pemisahan kekuasaan adalah sendi yang berfungsi sebagai instrumen yuridis yang utama untuk mencegah konsentrasi kekuasaan, rezim pemerintahan tirani dan tindakan sewenang-wenang pejabat publik. Setiap organ penyelenggara negara harus tunduk dan patuh terhadap pembatasan wewenang, tugas dan fungsi masing-masing yang ditetapkan dengan berpedoman pada sendi pemisahan kekuasaan sebagai sendi hukum konstitusional. Sudah barang tentu, setiap penyelenggara negara memahami konsekuensi yang akan terjadi jika sendi pemisahan kekuasaan dilanggar dalam praktik penyelenggaraan negara.

Dalam sistem ketatanegaraan Indonesia, sendi pemisahan kekuasaan adalah salah satu sendi hukum konstitusional yang utama selain sendi demokrasi. Dalam sistem ketatanegaraan Indonesia, batas-batas ruang lingkup wewenang, tugas dan fungsi setiap organ penyelenggara negara ditetapkan dengan berpedoman pada sendi pemisahan kekuasaan sebagai sendi hukum konstitusional yang utama untuk mencegah konsentrasi kekuasaan, rezim pemerintahan tirani dan tindakan sewenang-wenang penyelenggara negara. Dalam sistem ketatanegaraan Indonesia, sendi pemisahan kekuasaan diterapkan pertama-tama di antara organ-organ negara utama yakni MPR, DPR, DPD, PRESIDEN, MA, MK dan BPK. Dalam ruang lingkup yang lebih terbatas, sendi pemisahan kekuasaan juga diterapkan dalam lingkungan organisas pemerintah sehingga ada pembagian wewenang, tugas dan fungsi di antara aparat pemerintah mulai Presiden sampai kepada jabatan lain yang kedudukannya lebih rendah. Pemisahan kekuasaan dalam lingkungan jabatan pemerintah diatur dalam peraturan perundang-undangan yang sekaligus menjadi dasar hukum keberadaan setiap jabatan pemerintahan tersebut. hlm. 14

${ }^{18}$ Eric Barendt, Introduction to Constitutional Law (London, Oxford University Press, 1998),

${ }^{19}$ Sulardi, Menuju Sistem Pemerintahan Presidensil Murni (Malang, Setara Press, 2012), hlm. 40 . 
Dalam bingkai pemisahan kekuasaan yang diterapkan dalam lingkungan kekuasaan pemerintahan seperti dikemukakan di atas, batas-batas fungsi dan tugas BPKP diatur dalam Peraturan Presiden Nomor 192 Tahun 2014.Batas-batas fungsi dan tugas BPKP diatur sesuai dengan kehendak Presiden dan ditetapkan dalam Peraturan Presiden Nomor 192 Tahun 2014 sesuai dengan maksud dan tujuan pembentukan instansi tersebut dengan berpedoman pada sendi pemisahan kekuasaan. Jika berpedoman pada ketentuan Peraturan Presiden Nomor 192 Tahun 2014, batas-batas ruang lingkup tugas dan fungsi BPKP sebagai organ pengawas internal pemerintah adalah sangat terbatas. Sebagai suatu instansi pemerintahan, BPKP tidak memiliki wewenang sama sekali untuk melakukan suatu tindakan (perbuatan) hukum. BKP tidak memiliki wewenang untuk melakukan suatu tindakan (perbuatan) hukum kecuali tugas dan fungsi semata-mata.Kondisi BPKP sebagai instansi pemerintah yang tidak memiliki wewenang kecuali tugas dan fungsi membuktikan BPKP adalah bukan organ pemerintahan yang dapat dikategorikan sebagai subjek hukum mandiri dalam lalu lintas hukum.Keberadaan BPKP sebagai "organ pemerintah" yang tidak memiliki wewenang untuk melakukan suatu tindakan hukum membuktikan BPKP tidak berwenang menetapkan kerugian keuangan negara dalam tindak pidana korupsi sebagai perbuatan melawan hukum. Dalam penetapan kerugian keuangan negara dalam tindak pidana korupsi sebagai perbuatan melawan hukum, tindakan BPKPadalah tindakan (perbuatan) yang tidak memiliki dasar kewenangan berdasarkan undangundang atau peraturan perundang-undangan. Jika berpedoman pada ketentuan Peraturan Presiden Nomor 192 Tahun 2014, tindakan BPKP dalam penetapan kerugian keuangan negara dalam tindak pidana korupsi sebagai perbuatan melawan hukum adalah tindakan yang berada di luar tugas dan fungsinya sebagai organ pengawas internal pemerintah dengan fungsi dan tugas yang sangat terbatas.

Tindakan yang dilakukan BPKP dalam menetapkan kerugian keuangan negara dalam tindak pidana korupsi sebagai perbuatan melawan hukum adalah tindakan yang melanggar dan "merampas" wewenang BPK yang diatur dalam Pasal 10 UU Nomor 15 Tahun 2006 yang sudah dikemukakan di atas. Tindakan BPKP tersebut mengandung arti sebagai tindakan sewenang-wenang yang tidak memiliki landasan hukum undang-undang.Sebagai konsekuensinya, tindakan BPKP tersebut adalah tindakan yang melanggar batas-batas wewenang BPK sebagai badan pemeriksa keuangan yang diatur dan ditetapkan dalam Pasal 10 UU Nomor 15 Tahun 2006.Tindakan BPKP dengan karakteristik seperti dikemukakan di atas mencerminkan suatu jenis tindakan pelanggaran terhadap prinsip-prinsip kehidupan bernegara dan praktik penyelenggaraan negara dalam bingkai kehidupan bernegara ideal bangsa Indonesia yang disebut Negara Hukum Pancasila sebagai negara hukum kesejahteraan demokratis.Pelanggaran sendi pemisahan kekuasaan sebagai sendi kehidupan bernegara dan praktik penyelengagraan negara yang dilakukan BPKP adalah pelanggaran terhadap sendi konstitusional.Pelanggaran sendi pemisahan kekuasaan sebagai sendi hukum konstitusional negara kesatuan republik Indonesia yang dilakukan BPKP membuat sendi pemisahan kekuasaan yang ditetapkan dalam UUD 1945 dan UU Nomor 15 Tahun 2006 mengenai batasbatas wewenang, tugas dan fungsi BPK sebagai badan pemeriksa keuangan menjadi diabaikan.Tindakan BPKP dalam penetapan kerugian keuangan negara dalam tindak pidana korupsi sebagai perbuatan melawan hukum adalah tindakan yang melanggar batas-batas wewenang BPK yang ditetapkan berdasarkan sendi hukum 
konstitusional pemisahan kekuasaan.Sebagai konsekuensinya, tindakan BPKP dalam penetapan kerugian keuangan negara dalam tindak pidana korupsi sebagai perbuatan melawan hukum yang dikemukakan di atas adalah tindakan yang melanggar sendi hukum konstitusional pemisahan kekuasaan sebagai salah satu sendi hukum konstitusional utama Negara Hukum Pancasila.Pelanggaran sendi pemisahan kekuasaan tersebut merusak soko guru landasan konstitusional kehidupan bernegara dan praktik penyelenggaraan negara dalam bingkai Negaral Hukum Pancasila sebagai negara hukum kesejahteraan-demokratis.

Pelanggaran wewenang BPK oleh BPKP dalam penetapan kerugian keuangan negara dalam tindak pidana korupsi sebagai suatu perbuatan melawan hukum adalah suatu bentuk pelanggaran hukum. Sudah barang tentu, setiap pelanggaran hukum seperti pelanggaran hukum yang dilakukan BPKP dalam penetapaan kerugian keuangan negara dalam tindak pidana korupsi sebagai perbuatan melawan seperti disebut di atas akan melahirkan akibat hukum dan konsekuensi hukum tentu. Konsekuensi dan akibat hukum pelanggaran hukum yang dilakukan BPKP dalam tindak pidana korupsi sebagai perbuatan melawan hukum tersebutbelum tampak secara nyata dalam praktik penyelenggaraan negara pada saat sekarang. Namun, pelanggaran yang dilakukan BPKP dalam penetapan kerugian keuangan negara tersebut akanmelahirkan masalah hukum tertentu pada masa yang akan datang.

\section{PENUTUP}

\section{Simpulan}

Berdasarkan argumentasi yang dikemukakan di atas, penulis dapat membuat beberapa simpulan penelitian. Simpulan penelitian tersebut terdiri atas:

1. Tindakan BPKP dalam penetapan kerugian keuangan negara dalam tindak pidana korupsi sebagai perbuatan melawan hukum adalah tindakan sewenangwenang atau tidak yang dilakukan tanpa kewenangan.

2. Tindakan sewenang-wenang BPKP dalam menetapkan kerugian keuangan negara dalam tindak pidana korupsi sebagai perbuatan melawan hukum adalah tindakan yang melanggar sendi hukum pemisahan kekuasaan sebagai salah satu sendi utama kehidupan bernegara dan praktik penyelenggaraan negara dalam bingkai Negara Hukum Pancasila sebagai negara hukum kesejahteraan demokratis.

\section{Saran}

Dalam konteks dan bingkai dikursus yang dikemukakan di atas, penulis dapat mengemukakan beberapa saran. Saran yang dapat dikemukakan terdiri atas:

1. Amandemen undang-undang Nomor 39 Tahun 1999 juncto UU Nomor 20 Tahun 2001 serta UU Nomor 15 Tahun 2006 perlu dikakukan dengan segera untuk mencegah tindakan pelanggaran yang serupa yang dilakukan BPKP terjadi Kembali.

2. Dalam kedua undang-undang yang disebut di atas perlu ditambahkan satu ayat atau satu pasal sebagai berikut "Penetapan kerugian keuangan negara dalam tindak pidana korupsi sebagai perbuatan melawan hukum yang 
dilakukan organ lain selain Badan Pemeriksa Keuangan adalah tidak sah dan batasl demi hukum."

\section{Ucapan Terima Kasih}

Ucapan terima kasih layak dan patut disampaikan kepada pihak-pihak yang mendukung penelitian ini. Pihak-pihak yang dimaksud di atas adalah (1) Yayasan Barata Bhakti, (2) Rektor Universitas Bhayangkara Jaya dan staff, (3) Dekan Fakultas Hukum Universitas Bhayangkara Jaya dan staff, Lembaga Penelitian dan Pengabdian MasyarakatUniversitas Bhayangkara Jaya dan staff, (4) Dewan Redaksi Jurnal Sasana Program Studi Magister Ilmu HukumUniversitas Bhayangkara Jaya dan staff serta semua pihak yang tidak dapat disebut karena keterbatasan ruang dan tempat.

\section{DAFTAR PUSTAKA}

\section{Buku}

A'an Effendi dan Freddy Poernomo.Hukum Administrasi. Jakarta: Sinar Grafika, 2017.

Ahmad Fikri Hadin.Eksistensi Badan Pengawasan Keuangan dan Pembangunan di Era Otonomi Daerah. Yogjakarta, Bantul: Genta Press, 2013.

Andi Hamzah.Delik-delik Tertentu (Speciale Delicten) di dalam KUHP. Jakarta: Sinar Grafika, 2015.

Bachsan Mustafa.Pokok-pokok Hukum Administrasi Negara. Bandung: Alumni, 1979.

Barendt, Eric. Introduction to Constitutional Law. London: Oxford University Press, 1998.

Indroharto. 'Asas-asas Umum Pemerintahan Yang Baik' dalam Paulus Effendi Lotulung "Himpunan Makalah Azaz- azaz Umum Pemerintahan Yang Baik (A.A.U.P.B.). Bandung: Citra Aditya Bhakti, 1994.

Ridwan Khairandy, Hanafi Amrani dan Dolli Setiawan Ritonga.Korupsi Kerugian Keuangan Negara di BUMN. Yogjakarta: UII Press, 2018.

Sulardi.Menuju Sistem Pemerintahan Presidensil Murni. Malang: Setara Press, 2012.

Yopie Morya Immanuel Patiro.Diskresi Publik dan Tindak Pidana Korupsi. Bandung: Keni Media, 2012.

\section{B. Peraturan Perundang-undangan}

Negara Republik Indonesia, Undang-undang Dasar Tahun 1945.

Negara Republik Indonesia, Undang-undang Nomor 15 Tahun 2006. 
Jurnal Hukum Sasana, Volume 6 Nomor 1, Juni 2020

P-ISSN 2461-0453, E-ISSN 2722-3779

DOI: https://doi.org/10.31599/sasana.v6i1.263

Peraturan Presiden Nomor 192 Tahun 2014 tentang Badan Pemeriksa Keuangan dan Pembangunan.

Putusan PTUN Jakarta Timur Nomor: 111/G//20/2014/ \{ TUN Jkt,

Putusan PTUN Jakarta Nomor 250/G//2014 PTUN Jakarta,

Putusan PTUN Surabaya Nomor 09/G/2015/PTUN-Sby dan lain-lain.

Putusan Mahkamah Agung Nomor 302 K/PID.SUS/2017 tanggal 15 Maret 2017.

Putusan Mahkamah Konstitusi Nomor: 003/PUU-IV/2006. 